\title{
Corporate Governance and Risk Disclosures: A Comparative Analysis Between Bangladeshi and Malaysian Islamic Banks
}

\author{
Mohammad Rokibul Kabir ${ }^{1}$, Farid A. Sobhani ${ }^{2}$, Normah Omar $^{3}$ \& Norazida Mohamad ${ }^{3}$ \\ ${ }^{1}$ School of Business Administration, East Delta University, Chittagong, Bangladesh \\ ${ }^{2}$ Department of Business Administration, International Islamic University Chittagong, Chittagong, Bangladesh \\ ${ }^{3}$ Accounting Research Institute, Universiti Teknologi MARA, Malaysia \\ Correspondence: Farid A. Sobhani, Department of Business Administration, International Islamic University \\ Chittagong, Chittagong, Bangladesh.
}

Received: April 30, 2019

Accepted: May 30, 2019

Online Published: June 10, 2019

doi:10.5430/ijfr.v10n5p110

URL: https://doi.org/10.5430/ijfr.v10n5p110

\begin{abstract}
Corporate governance provides a fundamental framework to oversee corporate conduct and ensures transparency of institutions like banks. In case of Islamic banks, it adds additional importance as the profit sharing (with the depositors) system enhances the chance of agency problem for such institutions. Again, risks are inherent in institutions like Islamic banks, which necessitate the investors to get proper information about the risk encountered by the banks in which they invest. Thus, corporate governance and risk disclosures bear utmost importance. Since Malaysian banking industry has already experienced a favorable growth of Islamic banking and Bangladesh is observing a rapid growth of popularity of Islamic banking, a comparative study has been undertaken between Malaysian and Bangladeshi Islamic banks regarding corporate governance and risk disclosures in annual reports. Content analysis technique has been applied to facilitate the comparison. Both quantity and quality of risk reporting of the sample companies have been evaluated. A corporate governance disclosure index has been developed by following the guidelines provided by Bangladesh Security and Exchange Commission (BSEC) and the principles laid down in the 'Guidelines on Corporate Governance for Licensed Islamic Banks in Malaysia' to explore and compare the degree of good corporate governance and relevant disclosures in the annual reports. It is hypothesized that corporate governance and risk disclosure will vary between Malaysian and Bangladeshi Islamic Banks. It is also argued that the corporate risk disclosures will be positively associated with the quality of the firm's corporate governance mechanisms. Results are generally supportive of hypotheses. At the end, implications for theory and practices are discussed in the study.
\end{abstract}

Keywords: corporate governance, risk reporting, risk disclosure, Islamic banks, Bangladesh and Malaysia

\section{Introduction}

Though a good number of studies have been conducted in recent years concerning risk disclosure in annual report, the area of risk reporting is still very much unexplored. Over the years risk disclosures in the annual reports have been considered to be a critical aspect of corporate disclosure. Often risk and investment decisions are found to be closely related (Weber, Siebenmorgen \& Weber, 2005). The investors demand a tradeoff between the risk and return of investment and hence the financial reporting should contain information relevant to measure the risks and uncertainties concerning future performance of corporations. Undoubtedly, it is accepted by a wide range of people that risk disclosures ensure transparency and boost investors' confidence resulting the benefits of better market performance. (Abraham and Cox, 2007; Abraham and Shrives, 2014; Cabedo and Tirado, 2004). Though risk disclosure is the center of interest of a wide range of investors, researches have showed that the present risk reporting is not providing desired help to them and does not convey real meaning (Campbell \& Slack, 2008; Moxey \& Berendt, 2008). Again, recent researches examined the positive relation between good corporate governance and qualitative disclosures (e.g., Ramalingegowda and Yu 2012; García Lara, García Osma, and Penalva, 2009). Thus, all else equal, stronger governance leads to less manipulation and better disclosures. Good corporate governance is a prerequisite for the better performance of an organization. But recent accounting scandals have put corporate governance in the public spotlight. A series of major corporate accounting fraud scandals has renewed interest among academics and policymakers in the issues of corporate governance and Corporate-sector integrity (McDonough, 2002). 
Corporate governance is not only a fundamental framework to monitor companies' corporate conduct, it is also necessary for ensuring transparency of financial institutions like banks. Banks manage the funds of different account holders and investors and such activities of banks make it more important to emphasis on corporate governance in a greater extent than other corporate bodies because any delinquency from the bank side may have confrontational effect on its stakeholders and may conceivably stimulate the rise to agency issues and conflict of interest between the management and those who have exposed their faith in banking with the banks for superior management of their funds. Understanding the importance of corporate governance, many countries have established their own codes of conduct for effective corporate governance based on some common issues applicable throughout the world along with some country specific characteristics (Shahzad, Awan and Ahmed, 2013; Dincer \& Kilinç 2018).

Again as a financial institution banks are always exposed to different types of risk. It is even more important whenever Islamic banks are concerned as such banks operate on the basis of risk sharing under profit and loss sharing system (PLS). Thus, investors need to know risk faced by banks and as such the demand for risk disclosure in annual reports of banks have been increasing rapidly. Though Conventionally researchers mainly search for the quantity of information disclosed by firms, in recent years researches have served to remind users that the quality is more important than the quantity of the provided information (e.g. Hooks \& van Staden, 2011; Marston \& Shrives, 1991). Most of the earlier studies concerning risk reporting explored the quantity of disclosure, mainly conducted using words/sentences or some form of disclosure checklist (Abraham and Shrives, 2014; Dunst, et.al 2018). But this study is an attempt to analyze both quantity and quality of risk disclosures by the Islamic banks.

This paper, thus, seeks to explore the availability of corporate governance and risk disclosures in the annual reports of Bangladeshi and Malaysian Islamic banks. The primary objective is to know the non-financial part of annual reports for the existence and types of risk being disclosed along with corporate governance practices through content analysis. In addition, the study will search for quality of information on the basis of the recommendations provided by Abraham and Shrives in 2014.

The reasons for comparing between Bangladeshi and Malaysian banks' disclosure include several phenomena. Both Bangladesh and Malaysia enjoy the similar cultural atmosphere and a good relationship in terms of economic and financial affairs. Many people of Bangladesh are working in Malaysian and sending remittance through banking channel whereas money from Bangladesh are being channeled to Malaysia through banks for investment under "Malaysia Second Home Scheme". Money laundering and corporate transparency in the financial concerns are the prime issues for both countries in recent years. Thus, it is comprehended to conduct a comparative study between these two countries financial institutions like bank to make investors and other stakeholders understand how the banks are handling risk and transparency issues. There is a small number of studies in the field of risk disclosures in a multi country context except except researches like Dobler (2011) who studied the risk disclosure practices of U.K., U.S., Canadian, and German manufacturing firms in a multi-country sample and the work of Abdallah, et.al (2015) who studied comparative quantitative risk disclosures of Gulf countries. Specifically, empirical work has focused on the risk disclosure practices of financial (Oliveira Von, 2011; Hassan, 2014) and non-financial (Oliveira et al., 2011b; Madrigal, Blanco and Aibar, 2012; Elshandidy Fraser \& Hussainey, 2013; Durak \& Çankaya 2018) issues in the context of single-country studies.

Thus, this research is unique in the sense that it includes risk reporting of both Bangladeshi and Malaysian bank as well as it searches for both quantity and quality of risk disclosure and at the same time it explores the corporate governance of the sample banks and describes the relationship between risk reporting and good corporate governance.

\section{Literature Review and Hypotheses Development}

The financial transparency as reflected in the annual report through proper disclosures assures depositors, creditors and shareholders with credibility that they are free from deceitful operations. Thus, disclosure quality can be used as one of the most important measure of good corporate governance of a firm (Mitton, 2002 and Coles et. al, 2002; Imran \& Bakari 2018).

According to Abraham and Shrives (2014), Proprietary costs theory advocates that companies tend to disclose general and routine risk in their annual reports which are not specific to the firm characteristics rather standardized in nature and as such have no value to the users in understanding the real picture. It urges that the disclosure information should be both specific to the company and regularly updated.

Institutional theory suggests that real risks are not reflected in company disclosure though risk experiences need to be discussed in annual reports in the light of previous disclosures to confirm their coherence and authenticity. In brief, 
disclosures should include the discussion of real risk experiences.

\subsection{Country Effect}

A country's rules and regulations related with accounting and financial activities often motivates and sometimes obligate managers to ensure specific risk-related information disclosure in their annual reports which are applicable for that particular country over time (Cabedo and Tirado, 2004; Abraham and Cox, 2007; Linsley and Lawrance, 2007; Hassan, 2009; Poskitt, 2005; Lopes and Rodrigues, 2007; Ihsan, 2017). In fact, a country's regulatory framework and institutional norms influence the disclosure practices of that country to a great extent (DiMaggio and Powell, 1983). Thus, both of corporate governance and risk related disclosures of banks depend much on the country specific phenomena. The regulatory frameworks of both of Malaysia and Bangladesh contain provisions that require the disclosure of risk-related information as part of a broader approach to corporate governance. But the regulatory frameworks of two different countries are not the same. Thus, the mandatory information may differ on the basis of specific guidelines while voluntary disclosures in these areas are also expected to differ. However, whatever the guidelines provide, the quantity of disclosures may vary but the quality of such disclosures cannot be restricted within a framework.

The study of Abdallah, Hassan and McClelland (2015) identified a significant variation in the risk reporting as a part of a broader approach to corporate governance. Hence, a variation in the areas of risk reporting and corporate governance between Malaysian and Bangladeshi Islamic banks is also expected. It is a matter of fact that, the financial regulatory bodies and relevant laws in Malaysia are stronger than those of Bangladesh which are evident from economy of the countries as well as from the relevant reporting practices. For example, there were no specific rules to ensure responsibility and transparency in financial reporting till the official publication of the gazette for the Financial Reporting Act 2015 (known as FRA 2015) on September 9, 2015 as enacted in the Parliament of Bangladesh though the act is yet to play full-fledged role. Thus, the quantity of risk disclosures and corporate governance compliance of both of the country may vary and lead to the formation of the second and third hypotheses of the study.

$\mathrm{H}_{\mathrm{O} 1}$ : There is no difference in the quantity of corporate risk disclosures between Malaysian and Bangladeshi Islamic banks

$\mathrm{H}_{\mathrm{A} 1}$ : Corporate risk disclosures of Malaysian Islamic banks are better than Bangladeshi Islamic banks.

$\mathrm{H}_{\mathrm{O} 2}$ : There is no variation in the level of corporate governance disclosures between Malaysian and Bangladeshi Islamic banks.

$\mathrm{H}_{\mathrm{A} 2}$ : The level of corporate governance disclosures of Malaysian Islamic banks is better than Bangladeshi Islamic banks.

\subsection{Association Between Corporate Governance and Risk Disclosures}

Since managers do not hold the residual claim of a company, conflict of interest arises between the shareholders and the managers known as agency problem (Abdallah, 2015). Though managers do not possess of the residual ownership of a company, they have control over the affairs of that organization. Agency theorists have asserted that this set of conditions results from information asymmetry though the shareholders have the capacity to reduce information asymmetry by the implementation of good corporate governance which ensures proper check and balance of managerial activities.

Good corporate governance in banks reduces the possibility that information asymmetry will be misused in the betterment of the strategic managers as well as it pressurize top managers to disclose relevant risk-related information (Abdallah, 2015; Ebire, Onmonya \& Inim 2018). Thus, good corporate governance ensures better disclosures of risk related information to the firm's shareholders (Chen and Jaggi, 2000; Eng and Mak, 2003; Gul and Leung, 2004; Healy and Palepu, 2001). Hence, it is argued that information asymmetry can be reduced by ensuring better corporate governance which will, in turn, positively influence disclosure of corporate risk. Thus, the following hypothesis can be formulated:

$\mathrm{H}_{\mathrm{O} 3}$ : There is no association between corporate risk disclosure and good corporate governance

$\mathrm{H}_{\mathrm{A} 3}$ : Corporate risk disclosure will be positively associated with good corporate governance

\section{Theoretical Perspective}

There is hardly any comprehensive theory providing discretionary disclosure framework. Discretionary disclosures for a particular study determine the selection of the theory apparently though even then practice is inconsistent within 
a theoretical framework and it remains as a challenge (Cormier, Magnan, \& van Velthoven, 2005). When there is no dominant theory in operation, a multi-theoretic approach is often applicable to ensure a base for study. Such application of multi-theoretic approach is often seen in literatures of disclosures. In the field of corporate governance disclosure agency theory is often used as a base. Separation of ownership and control influences the agency problems in corporate body. Sometime, directors try to maximize their own interest by hidden action of adverse selection of veiled information at the expenses of shareholders (Jensen and Meckling, 1976). Thus, the presence of agency cost is the main issue in the agency theory (Berger and Patti, 2006). Good corporate governance can help in minimizing this cost (Gursoy \& Aydogan, 2002) because it ensures goal congruence among the shareholders (principals) and the directors and management team (agents) (Conyon and Schwalbach, 2000). In fact, to monitor the decision making process of the management team in favor of stockholders, good corporate governance is a must. It ensures that the decisions of the directors are in line with shareholders' interests. Corporate governance also plays role in motivating managerial activities to achieve the goal of a company i.e. the maximization of firms' wealth (Cheung and Chan 2004; Inan, 2018).

Though a good number of the theories are occasionally useful for explaining corporate risk disclosures in the annual report, this study privileges institutional theory alongside proprietary costs theory because these two theories explain the necessity of risk disclosure comparatively better than other theories. In fact, the reasons of selecting institutional theory and proprietary costs theory are many. Firstly, they offer a way of describing and understanding the obstacles of risk reporting at present. Secondly, the theories can consider various dimensions of risk reporting both in concert and independently. Thirdly, the theories can help separating the general disclosures which bear little or no relation to the risk identification and management processes within organizations. Finally, the imitative characteristics of institutional theory could be helpful in visualizing the present constraints of risk reporting. In fact, application of these designated complementary and interconnecting theories ensures greater insight than using just one economic theory (Cormier et al., 2005; Eketu, 2018).

\subsection{Agency Theory}

So called contractual view of the firm, developed by Coase (1937), Jensen and Meckling (1976) explain emergence of the agency problem. The crux of the agency problem is the separation of proprietorship and control. A manager needs fund to utilize for production and earning return. He needs the investors' funds because he either does not have sufficient capital of his own to invest or else wants to cash out his holdings. Here the question arises about how investors could be assured that their fund would be returned with profit. The agency problem in this perspective refers to the worries investors have in guaranteeing that their funds are not confiscated or misused on repellent projects.

The agency problems in Islamic financial institutions are unique to other financial institutions and they need separate and different ways of examining and solving these issues (Shahzad, Awan, and Ahmed 2013). Along with the responsibilities of maximizing shareholders wealth managers of Islamic banks are beholden to work under Shari'ah guidance (Archer, Karim and Deehani 1998). The necessity of conforming to Shari'ah regulations creates the difference between the traditional finance and Islamic modes (Sarker, 1999). In Islamic modes (e.g Mudaraba), the managers get an opportunity to share in profits and not in the losses. Thus, the agency problem is more complicated in Islamic banks (Karim, 2001). Hence, the Islamic banks should give a separate segment of such governance in their annual reports as they are the financial institutions that put efforts both into ensuring maximizing of the funds of their investors and look after the society as a whole in a Shari'ah-compliant manner (Safieddine, 2009).

\subsection{Proprietary Costs Theory}

Verrecchia (1983) developed the Proprietary Costs theory and suggested that the choice to disclose information is a function of the substantial costs of such disclosures. When there is any reduction of future generation of cash flow due to certain information, it is called to be a cost of disclosing that information. Proprietary costs theory exemplifies the costs and relevant benefits of disclosure. In practice, most of the companies have their own risk management systems but often they remain unenthusiastic to publish sensitive risk related information (Marshall \& Weetman, 2007). Hence, sometime a mismatch is observed between the actual risk exposure of the company and the risk disclosed by the company in the annual report as the managers remain confused about what actually needs to be disclosed. The root of such dilemma is that if managers fail to disclose materially important risks element, the investors and other stakeholders may be unhappy as they remain in dark about the real exposure of risk. On the other hand if they disclose all sorts of present and expected risks of the company, there is a possibility that they will incur proprietary costs. Therefore, in choosing appropriate disclosure strategy managers try to trade off the benefits of disclosing risk related items and the cost of disclosing sensitive information. In determining disclosure strategy cost 
of such disclosure is a critical issue as evident from the earlier studies (Cormier et al., 2005). Thus, the theme of Proprietary cost theory is that the disclosure information should be regularly updated and specific to the company and company managers should evaluate risk disclosures on a regular basis within annual reports.

\subsection{Institutional Theory}

Institutional theory refers that the presence of political and socioeconomic perspectives effects disclosure decisions and prevents it to be a pure economic decision (Oliver, 1991). Managers of companies with good reputations often continue mimicking other fabled companies' disclosures because of cost benefit uncertainties and keeping their reputation uphold by signaling that their risk management systems are equivalent to the industry standard (Dillard, Rigsby, \& Goodman, 2004).

According to the Institutional theory, where the magnitudes of the disclosures are uncertain, the managers become reluctant to bring changes in the pattern and types of information disclosures they are using for long. Thus, companies use standardized disclosures over the period which cost no or less incremental disclosure costs. Standardized risk disclosures over the period may be validated from legal point of view but no real content is provided to be useful to the users in real sense. Their edifice is unquestionable but they are ironically useless (Raffaele, 2006). Hence, the theme of Institutional theory is that the disclosures within annual reports should incorporate the discussion of actual risk experiences though the managers remain reluctant to do so.

\subsection{Proprietary Costs Theory and Institutional Theory to Explain Risk Disclosure}

Proprietary costs theory and institutional theory often work together in influencing against good disclosures. Both proprietary costs theory and institutional theory inspire the publication of general and routine disclosures without considering bank specific characteristics and real risk experiences.

In fact, the reasons of poor and lack of relevant risk disclosures by the companies as evident from earlier studies can be explained through the combination of these two theories. These theories together can describe the problem of ineffectiveness of present risk disclosures and the contents of risk disclosures to be effective in decision making (Abraham and Shrives, 2014).

\section{Methodology of the Study}

\subsection{Sample Selection, Study Period and Data Collection}

The study is conducted to facilitate a comparative analysis of corporate governance and risk disclosures in the annual reports of the Islamic banks in Bangladesh and Malaysia. There are seven (07) listed Islamic banks in Bangladesh all of which are selected as sample. On the other hand there are sixteen Islamic banks in Malaysia but to facilitate the comparison with Bangladesh Islamic banks seven (07) banks have been selected randomly. Thus, the study samples consist of fourteen Islamic banks as highlighted below:

\begin{tabular}{ll}
\hline Bangladeshi Islamic Banks & Malaysian Islamic Banks \\
\hline AL-Arafah Islami Bank LTD & Affin Islamic Bank Berhad \\
Export Import Bank of Bagladesh LTD & Alliance Bank Malaysia Berhad \\
First-Sequrity Islami Bank LTD & Al Rajhi Banking \& Investment Corporation (Malaysia) Berhad \\
Islami Bank Bangladesh LTD. & AmBank Islamic Berhad \\
ICB Islamic Bank LTD & Bank Islam Malaysia Berhad \\
Shahjalal Islami Bank LTD & Bank Muamalat Malaysia Berhad \\
Social Islami Bank LTD & CIMB Islamic Bank Berhad \\
\hline
\end{tabular}

The study considers the data of the sample banks from 2011 to 2015. Annual reports of the sample banks for all the years as collected from the websites of the respective banks are main sources of data. Content analysis has been used to survey for the required investigation in the non-financial section of the annual reports.

\subsection{Content Analysis and Disclosure Index for Corporate Governance}

In line with the other disclosure studies similar to this, we employed content analysis on annual reports of the sample companies. Content analysis is a technique involves identification of contents within text under different themes or 
categories (Momin and Hossain, 2011).

To explore the corporate governance practices of the sample companies, a disclosure index has been used. The index is constructed following the guidelines provided earlier by Karim et.al (2010). Dichotomous technique has been used in the index where there are 33 disclosure variables (See Appendix-i) under six heads. The variable to be considered under the six heads have been selected through the analysis of the guidelines provided by Bangladesh Security and Exchange Commission (BSEC) for corporate governance of the listed companies in 2016 and the guideline provided by Bangladesh Bank, the central bank of Bangladesh along with the Malaysian Code on Corporate Governance by Finance Committee on Corporate Governance, Guidelines on Corporate Governance for Licensed Islamic Banks in Malaysia, Capital Market Master Plan (CMP) by Securities Commission of Malaysia and Financial Sector Master Plan (FSMP) by Bank Nagara Malaysia, the central bank of Malaysia. The items so selected from the guidelines described above are important to consider for all cases beyond the boundaries.

The following formula can be used to identify the corporate governance disclosures under the six different heads.

$$
\sum \mathrm{CGD}=\sum \mathrm{COB}+\sum \mathrm{ROD}+\sum \mathrm{IKI}+\sum \mathrm{CAC}+\sum \mathrm{CAR}+\sum \mathrm{CSB}
$$

Where,

$\sum \mathrm{CGD}=$ Corporate Governance Disclosures

$\sum \mathrm{COB}=$ Constitution of Board of Directors

$\sum \mathrm{ROD}=$ Report of Directors

$\sum \mathrm{IKI}=$ Information of Key Issues

$\sum \mathrm{CAC}=$ Constitution of Audit Committee

$\Sigma \mathrm{CAR}=$ Contents Audit Report

$\sum \mathrm{CSB}=$ Constitution of Shariah Board

In case of complying with a particular variable item, one (1) is assigned, for not complying with a particular variable, zero (0) is assigned. However, the important characteristic of the study is that if a particular variable is not relevant to a certain company, it is not considered to measure the score of that company. Thus, the scores are expressed in percentage form to facilitate comparison. The disclosure model explores the scores as follows:

Total Disclosure, $\mathrm{CGD}=\sum \mathrm{di}$

Disclosure Index $(\mathrm{di})=\mathrm{m} / \mathrm{n} * 100$

Where,

$\mathrm{d}=1$, if the information item (ith relevant item) is disclosed.

$\mathrm{d}=0$, if the information item (ith relevant item) is not disclosed.

$\mathrm{m}=$ the number of variables which the company actually disclosed.

$\mathrm{n}=$ the number of variables which the company is expected to disclose.

\subsection{Content Analysis for Risk Reporting}

The study evaluates both quantity and quality of risk disclosures in annual reports of the sample companies. Quantity of risk disclosures has been identified by observing the number of sentences in the annual report of a bank whereas qualitative risk disclosure has been evaluated by answering the questions arises from Proprietary cost theory and Institutional theory. Thus, the non-financial sections of the annual reports of the sample companies from the year 2011 to 2015 have been examined to seek the following issues:

i) Whether the disclosed information are specific to the company or general in nature;

ii) Whether the disclosed information are same or similar over the time period examined;

iii) Whether the disclosed information explained how a particular risk factor is relevant to a specific financial year and how it would help in future strategy formulation

iv) Whether there is any explanation of why a particular risk factor is added to or removed from risk statement.

v) Whether disclosures within annual reports included the discussion of actual risk experiences

\subsection{Test of Hypotheses}

To test the hypotheses formulated in the earlier part of the study we took two different statistical tools. For 
comparing the level of corporate governance disclosure compliance and risk disclosures between Bangladeshi and Malaysian Islamic banks, we conducted t-test. Again to find whether there is any significant association between good corporate governance and risk reporting, correlation analysis has been done. For all the cases computer aided statistical software called SPSS-20 has been used.

\section{Results and Discussions}

\subsection{Risk Reporting in Terms of Quantities}

The quantity of risk disclosures of the sample Islamic banks have been measured in terms of number of sentences used by them in their annual reports as explored though the content analysis of the non-financial sections from the year 2011 to 2015 as highlighted in the following table-1 and table-2 for Bangladeshi and Malaysian Islamic banks respectively.

5.1.1 Risk Reporting of Bangladesh Islamic Banks in Terms of Quantity

Table 1. Number of sentences used by Bangladesh Islamic banks to describe risk

\begin{tabular}{llllllll}
\hline \multirow{2}{*}{ Year } & \multicolumn{2}{l}{ Name of Banks } & & & & \\
\cline { 2 - 8 } & AIBL & EXIMBL & FSIBL & ICBIBL & IBBL & SIBL & SJIBL \\
\hline 2011 & 159.00 & 356.00 & 256.00 & 97.00 & 355.00 & 345.00 & 463.00 \\
\hline 2012 & 174.00 & 386.00 & 265.00 & 103.00 & 342.00 & 359.00 & 464.00 \\
\hline 2013 & 193.00 & 414.00 & 276.00 & 102.00 & 384.00 & 402.00 & 468.00 \\
\hline 2014 & 205.00 & 415.00 & 321.00 & 132.00 & 398.00 & 452.00 & 476.00 \\
\hline 2015 & 212.00 & 472.00 & 345.00 & 118.00 & 489.00 & 543.00 & 565.00 \\
\hline Average & 188.60 & 408.60 & 292.60 & 110.40 & 393.60 & 420.20 & 487.20 \\
\hline Mean of Average score & 328.74 & & & & & & \\
\hline
\end{tabular}

Table 1 highlights the number of sentences used by the Islamic banks in Bangladesh for risk reporting. All the banks except ICB Islamic Bank Ltd (ICBIBL) have shown a continuous increase in disclosures in terms of number of sentences used. The highest average disclosures of the study period is found to be 489.00 scored by Shahjalal Islami Bank Ltd (SJIBL) while the lowest average number of sentences (110.40) is disclosed by ICB Islamic Bank Ltd (ICBIBL). Among all the years and all the banks, the highest number of sentences used to describe risk is 565 by Shahjalal Islami Bank Ltd (SJIBL) in 2015 whereas the lowest number of sentences used to describe risk is 97 by ICB Islamic Bank Ltd (ICBIBL) in 2011.

5.1.2 Risk Reporting of Malaysian Islamic Banks in Terms of Quantity

Table 2. Number of sentences used by Malaysian Islamic banks to describe risk

\begin{tabular}{llllllll}
\hline Year & \multicolumn{2}{l}{ Name of Banks } \\
\cline { 2 - 8 } & AFFINIB & ALLNIB & AMIB & ALRAJI & BIM & BM & CIMB \\
\hline 2011 & 472.00 & 650.00 & 1032.00 & 315.00 & 905.00 & 942.00 & 420.00 \\
\hline 2012 & 482.00 & 642.00 & 1012.00 & 312.00 & 930.00 & 1028.00 & 724.00 \\
\hline 2013 & 502.00 & 709.00 & 1007.00 & 313.00 & 955.00 & 862.00 & 715.00 \\
\hline 2014 & 518.00 & 679.00 & 992.00 & 290.00 & 1030.00 & 952.00 & 722.00 \\
\hline 2015 & 488.00 & 639.00 & 969.00 & 178.00 & 924.00 & 1079.00 & 731.00 \\
\hline Average & 472.00 & 663.80 & 1002.40 & 281.60 & 948.80 & 972.60 & 662.40 \\
\hline Mean of Average score & 571.95 & & & & & & \\
\hline
\end{tabular}

Table 2 highlights the number of sentences used by the Islamic banks in Malaysia for risk reporting. Though a 
variation is observed among the sample Islamic banks in risk reporting in terms of sentences used, no trend of increase from year 2011 to 2015 has been discovered. The highest average disclosures of the study period is found to be 1002.40 scored by AM Bank Islamic Berhad (AMIB) while the lowest average number of sentences (281.60) is disclosed by Al Rajhi Banking \& Investment Corporation Malaysia Berhad (ALRAJI). Among all the years and all the banks, the highest number of sentences used to describe risk is 1079 by Bank Muamalat Malaysia Berhad (BM) in 2015 whereas the lowest number of sentences used to describe risk is 178 by Al Rajhi Banking \& Investment Corporation Malaysia Berhad (ALRAJI) in 2015. It is important to note that the number of sentences used by Al Rajhi Banking \& Investment Corporation Malaysia Berhad (ALRAJI) is very poor in comparison of other banks.Even if we consider average disclosures of all the banks of all the years (571.95), it will be clear that the average disclosure of ALRAJI (281.60) is less than half of mean of average. It is worth mentioning that ALRAJI is a foreign bank operating in Malaysia ((Ahmed, Khalid, Ammar \& Shah, 2017).

\subsubsection{Comparison on Risk Reporting Between Bangladeshi and Malaysian Islamic Banks}

If we consider the results shown it table 1 and table 2, it becomes evident that the average risk related sentences of Malaysian Islamic banks is about 1.75 times of that of Bangladeshi Islamic banks as the mean of average in case of Malaysian Islamic banks is 571.95 against the mean of average of Bangladesh Islamic banks of 328.74.

To test whether the risk reporting practices (number of sentences used to describe risk) in Malaysian Islamic banks are better than Bangladeshi Islamic banks we initiated the null hypothesis, $\mathrm{H}_{\mathrm{O} 1}$ : There is no variation in the quantity of corporate risk disclosures between Malaysian and Bangladeshi Islamic banks against the alternative hypothesis, $\mathrm{H}_{\mathrm{A} 1}$ : Corporate risk disclosures of Malaysian Islamic banks will be higher than Bangladeshi Islamic banks. T-test has been applied to check the hypothesis and the following Table 3 highlights the results.

Table 3. Paired samples t-test for risk reporting: Bangladeshi banks and Malaysian banks

\begin{tabular}{|c|c|c|c|c|c|}
\hline & Mean & $N$ & Std. Deviation & $\mathrm{T}$ & Sig. \\
\hline Risk Related Sentences: Bangladeshi Banks & 328.7429 & 35 & 135.72168 & & \\
\hline Risk Related Sentences: Malaysian Banks & 717.7143 & 35 & 263.66630 & & \\
\hline $\begin{array}{l}\text { Risk Related Sentences: Bangladeshi Banks } \\
\text { and Malaysian Banks }\end{array}$ & -388.97143 & $34 \mathrm{df}$ & 348.73119 & -6.599 & .000 \\
\hline
\end{tabular}

Table 3 shows the results of t-test where we find that the p vale is .000 indicating the significance of the test. From this result, we can say that the null hypothesis may be rejected at $99 \%$ confidence level. Again the mean value of Malaysian Islamic banks is higher than that of Bangladeshi Islamic banks ( $\left.\mathrm{RRS}_{\mathrm{MIB}}, 717.7143>\mathrm{RRS}_{\mathrm{BIB}} 328.7429\right)$. Thus, our alternative hypothesis is accepted and hence we can conclude that corporate risk disclosures (in terms of number of sentences) of Malaysian Islamic banks are higher than that of Bangladeshi Islamic banks (Suryanto, Haseeb, \& Hartani, 2018).

\subsection{Risk Reporting in Terms of Quality}

The quality of the risk reporting has been tested by seeking the answers of five (05) questions as suggested by Abraham (2014). The answer of the first question regarding type of information disclosed is unsatisfactory. In all the sample Islamic banks of both Bangladesh and Malaysia, the risk related information is more of general in nature instead of being specific. In most of the cases, the banks tend to disclose under the headings of 'Risk Management' or 'Risk Management Report' or 'Risk Reporting' and risk disclosure for 'BASEL 2 PILLAR 3 DISCLOSURES. Almost all the banks described the risks in general perspectives and categorized it as Credit Risk, Market Risk, Liquidity Risk and Operational without having a deep insight into the specific outlook.

The second and the third issues we considered to be critical for being a quality disclosure. These two refer the similarity or dissimilarity of disclosed information over the time period examined as well as the ability of the disclosed information to explain the way a particular risk factor is relevant to a specific financial year and how it would help in future strategy formulation. The study reveals that the Bangladeshi Islamic banks have a little change in describing risk over the time period though in true sense it does not mean that it described the way a particular risk factor is associated with a particular year (Jermsittiparsert, 2016). On the other hand, no significant change has been 
observed over the period in describing risk by the Malaysian banks during the study period.

None of the Bangladeshi Islamic banks has given any explanation about the reason for adding or removing a particular risk factor even though there are additions in risk related issues in almost all the years. On the other hand, in case of Malaysian Islamic banks there is rarely significant addition or removal of risk factor over the study periods though some explanations are revealed for a few issues. Thus, the answer of the fourth question we seek to get answered is disappointing once again.

The poorest area of risk disclosures for both of the countries' is exposed when the answer of the fifth question is revealed as it is found that the disclosures in the annual reports do not include the discussions of actual risk experiences. The banking sector in Bangladesh has been passing a critical phase since 2014 with investment recession and big financial scams. Many of the sample banks have already undergone bitter experiences regarding the issue and relevant risks are threatening. Unfortunately, no such actual risk experience has been described in the annual reports of the banks neither the policies regarding the risk related issues have been considered to disclose.

Thus, it can be concluded that the above discussions regarding the quality of risk reporting clearly support the Proprietary Cost Theory and Institutional Theory that the contents of risk disclosures are not effective in decision making as the banks have a common tendency to mimic the risk reporting practices of the industry. The banks do not update the risk information over the period or event and even do not share real risk experiences in fear of destructing own reputation through bad news.

\subsection{Corporate Governance and Relevant Disclosures}

The corporate governance disclosure index as prepared to examine the way of complying with reporting guidelines have shown a better result than that of risk reporting. The percentage of Corporate Governance Disclosure (CGD) under six different heads are highlighted in Table 4 and Table 5 for Bangladeshi and Malaysian Islamic banks respectively.

5.3.1 Corporate Governance and Relevant Disclosures in Bangladeshi Islamic Banks

Table 4. Corrected Segment Score (CSS), \% and average \% of score achieved for BD banks

\begin{tabular}{lllllllll}
\hline Category & $I B B L$ & $A I B L$ & $S I B L$ & $E X I M$ & $F S I B L$ & SJIBL & $I C B$ & Average \\
\hline Constitution of BOD (CSS) & 09 & 09 & 09 & 09 & 09 & 09 & 09 & 09 \\
\hline$\%$ & $\mathbf{1 0 0}$ & $\mathbf{7 0}$ & $\mathbf{8 0}$ & $\mathbf{8 0}$ & $\mathbf{9 0}$ & $\mathbf{8 0}$ & $\mathbf{9 0}$ & $\mathbf{8 4 . 2 8}$ \\
\hline Report of Directors (CSS) & 08 & 08 & 08 & 08 & 08 & 08 & 08 & 08 \\
\hline$\%$ & $\mathbf{1 0 0}$ & $\mathbf{9 0}$ & $\mathbf{8 0}$ & $\mathbf{1 0 0}$ & $\mathbf{9 0}$ & $\mathbf{9 0}$ & $\mathbf{1 0 0}$ & $\mathbf{9 2 . 8 6}$ \\
\hline Key Information (CSS) & 04 & 04 & 04 & 04 & 04 & 04 & 04 & 04 \\
\hline$\%$ & $\mathbf{5 0}$ & $\mathbf{7 5}$ & $\mathbf{5 0}$ & $\mathbf{7 5}$ & $\mathbf{7 5}$ & $\mathbf{5 0}$ & $\mathbf{7 5}$ & $\mathbf{6 4 . 2 9}$ \\
\hline Audit Committee (CSS) & 02 & 02 & 02 & 02 & 02 & 02 & 02 & 02 \\
\hline$\%$ & $\mathbf{1 0 0}$ & $\mathbf{5 0}$ & $\mathbf{5 0}$ & $\mathbf{5 0}$ & $\mathbf{5 0}$ & $\mathbf{1 0 0}$ & $\mathbf{5 0}$ & $\mathbf{6 4 . 2 9}$ \\
\hline Audit Report (CSS) & 03 & 03 & 03 & 03 & 03 & 03 & 03 & 03 \\
\hline$\%$ & $\mathbf{1 0 0}$ & $\mathbf{6 7}$ & $\mathbf{6 7}$ & $\mathbf{1 0 0}$ & $\mathbf{6 7}$ & $\mathbf{3 3}$ & $\mathbf{1 0 0}$ & $\mathbf{7 6 . 2 9}$ \\
\hline Constitution of Shariah Board (CSS) & 04 & 04 & 04 & 04 & 04 & 04 & 04 & O4 \\
\hline \% & $\mathbf{1 0 0}$ & $\mathbf{7 5}$ & $\mathbf{7 5}$ & $\mathbf{1 0 0}$ & $\mathbf{5 0}$ & $\mathbf{7 5}$ & $\mathbf{1 0 0}$ & $\mathbf{8 2 . 1 4}$ \\
\hline Total Corrected Score & 30 & 30 & 30 & 30 & 30 & 30 & 30 & 30 \\
\hline Score Achieved & 28 & 21 & 21 & 26 & 24 & 22 & 26 & 24 \\
\hline$\%$ in Total & 93 & 70 & 70 & 87 & 80 & 73 & 87 & $\mathbf{8 0 \%}$ \\
\hline
\end{tabular}

The above Table 4 shows the results of disclosure percentage of Bangladeshi Islamic banks where there are nine (09) items related to the constitution of board and only Islami Bank Bangladesh Limited (IBBL) disclosed 100\% of the items. Average disclosure percentage under this head is $84.38 \%$. 
There are nine (09) items under the head of Report of Board of Directors but as all the banks have declared dividend (reason for not declaring dividend, if any, is one of the point) during the period of study, the corrected segment total became eight (08). Three banks called Islami Bank Bangladesh Limited (IBBL), First Security Islami Bank Limited (FSIBL) and ICB Islamic Bank Ltd (ICBIBL) disclosed 100\% of the items. The mean disclosure percentage under this head is $92.86 \%$.

Five (5) Key issues need to be discussed under the CGD index but the corrected segment items are four (04). No Islamic bank has complied hundred percent nor a single company disclosed information of spouse and minor children of Directors, CEO, Company Secretary, CFO and Head of Internal Audit. Average disclosure percentage in this segment is $64.29 \%$.

There are two (02) items about constitution of audit committee. Again, there are four (04) items about the audit report but one item is not applicable for any of the sample banks indicating three (03) items in this segment. Both of Islami Bank Bangladesh Limited (IBBL) and Shahjalal Islami Bank Ltd (SJIBL) have 100\% percent compliance while the mean compliance about the constitution of audit committee is $64.29 \%$. IBBL, ICBIBL and EXIM Bank Ltd have $100 \%$ compliance with the CGD guidelines for information in the audit report. Average compliance rate in this case is $76.29 \%$. The mean compliance percentage on the constitution of Sharia Board is $82.14 \%$ where there are four (04) items. 100\% complied banks are IBBL, ICBIBL and EXIM Bank Ltd.

Considering all the items the highest complied bank is IBBL with a rate of $93 \%$ compliance and the lowest complied banks are Al Arafah Islamic Bank Limited (AIBL) and Social Islami Bank Limited (SIBL) with a compliance rate of $70 \%$. The mean compliance rate of all the banks for all the years is $80 \%$.

5.3.2 Corporate Governance and Relevant Disclosures in Malaysian Islamic Banks

Table 5. Corrected Segment Score (CSS), \% and average \% of score achieved for Malaysian Islamic banks

\begin{tabular}{lllllllll}
\hline Category & AFIB & ALIB & AMIB & ARIBL & BIM & BM & CIMB & Average \\
\hline Constitution of BOD (CSS) & 09 & 09 & 09 & 09 & 09 & 09 & 09 & 09 \\
\hline$\%$ & $\mathbf{8 9}$ & $\mathbf{1 0 0}$ & $\mathbf{1 0 0}$ & $\mathbf{4 5}$ & $\mathbf{1 0 0}$ & $\mathbf{1 0 0}$ & $\mathbf{1 0 0}$ & $\mathbf{9 0 . 5 7}$ \\
\hline Report of Directors (CSS) & 08 & 09 & 08 & 08 & 08 & 08 & 08 & 8.14 \\
\hline$\%$ & $\mathbf{1 0 0}$ & $\mathbf{8 9}$ & $\mathbf{1 0 0}$ & $\mathbf{7 5}$ & $\mathbf{1 0 0}$ & $\mathbf{1 0 0}$ & $\mathbf{8 9}$ & $\mathbf{9 3 . 2 8}$ \\
\hline Key Information (CSS) & 04 & 04 & 05 & 05 & 04 & 04 & 05 & 4.43 \\
\hline$\%$ & $\mathbf{7 5}$ & $\mathbf{7 5}$ & $\mathbf{7 5}$ & $\mathbf{2 0}$ & $\mathbf{7 5}$ & $\mathbf{7 5}$ & $\mathbf{8 0}$ & $\mathbf{6 7 . 8 5}$ \\
\hline Audit Committee (CSS) & 02 & 02 & 02 & 02 & 02 & 02 & 02 & 02 \\
\hline$\%$ & $\mathbf{1 0 0}$ & $\mathbf{1 0 0}$ & $\mathbf{1 0 0}$ & $\mathbf{1 0 0}$ & $\mathbf{1 0 0}$ & $\mathbf{1 0 0}$ & $\mathbf{1 0 0}$ & $\mathbf{1 0 0}$ \\
\hline Audit Report (CSS) & 02 & 02 & 02 & 02 & 03 & 03 & 02 & 02 \\
\hline$\%$ & $\mathbf{5 0}$ & $\mathbf{5 0}$ & $\mathbf{5 0}$ & $\mathbf{5 0}$ & $\mathbf{6 7}$ & $\mathbf{6 7}$ & $\mathbf{5 0}$ & $\mathbf{5 4 . 8 6}$ \\
\hline Constitution of Shariah Board (CSS) & 04 & 04 & 04 & 04 & 04 & 04 & 04 & 04 \\
\hline \% & $\mathbf{7 5}$ & $\mathbf{7 5}$ & $\mathbf{1 0 0}$ & $\mathbf{5 0}$ & $\mathbf{5 0}$ & $\mathbf{5 0}$ & $\mathbf{7 5}$ & $\mathbf{6 7 . 8 6}$ \\
\hline Total Corrected Score & 29 & 30 & 30 & 30 & 30 & 30 & 30 & 30 \\
\hline Score Achieved & 22 & 27 & 28 & 16 & 28 & 28 & 26 & 24 \\
\hline$\%$ in Total & $\mathbf{7 6}$ & $\mathbf{9 0}$ & $\mathbf{9 3}$ & $\mathbf{5 3}$ & $\mathbf{9 3}$ & $\mathbf{9 3}$ & $\mathbf{8 7}$ & $\mathbf{8 4 \%}$ \\
\hline
\end{tabular}

The above Table 5 shows the results of disclosure percentage of Malaysian Islamic banks from 2011 to 2015. There are nine (09) items related to the constitution of board and all the banks except Affin Islamic Bank and Alraji Islamic Bank have disclosed 100\% of the items where Affin Islamic bank disclosed 89\% and Alraji Islamic Bank disclosed $45 \%$ items on an average in the last five years. Average disclosure percentage under this head is $90.57 \%$.

There are nine (09) items under the head of Report of Board of Directors but as all the banks except Alliance Islamic Bank have declared dividend during the period of study the corrected segment total became eight $(08)$ for the six banks and nine (09) for Alliance Islamic Bank. Four banks called Affin Islamic Bank, Am Islamic Bank, Bank Islam 
Malaysia and Bank Muamalat disclosed $100 \%$ of the items. The mean disclosure percentage under this head is $93.28 \%$.

Five (5) Key issues need to be discussed under the CGD index but the corrected segment items for four banks are four (04). No Islamic bank has complied hundred percent nor a single company disclosed information of spouse and minor children of Directors, CEO, Company Secretary, CFO and Head of Internal Audit. Average disclosure percentage in this segment is $67.85 \%$.

There are two (02) items about constitution of audit committee and four (04) items about the audit report but one item is not applicable for any of the sample bank indicating a corrected score of three (03). All the banks have achieved 100\% score. None of the banks have 100\% compliance with the CGD guidelines for information in the audit report. Average compliance rate in this case is $54.86 \%$. The mean compliance percentage on the constitution of Shariah Board is $67.86 \%$. Only Am Islamic bank has $100 \%$ compliance in this case.

Considering all the items, the highest complied banks are Am Islamic Bank, Bank Islam Malaysia and Bank Muamalat with a compliance rate of $93 \%$ and the lowest complied bank is Alraji Islamic Bank with a compliance rate of 53\%. The mean compliance rate of all the banks for all the years is $84 \%$.

\subsubsection{Comparison on Risk Reporting Between Bangladeshi and Malaysian Islamic Banks}

If we consider the results shown it Table 4 and Table 5, it can be observed that the mean corporate governance disclosure compliance percentage of Malaysian Islamic banks is greater than that of Bangladeshi Islamic banks as the mean of average of all the banks for all the years in case of Malaysian Islamic banks is $84 \%$ against that of Bangladesh Islamic banks of $80 \%$.

To test whether the good corporate governance disclosure compliance in Malaysian Islamic banks is significantly better than Bangladeshi Islamic banks, we initiated the null hypothesis, $\mathrm{H}_{\mathrm{O} 1}$ : There is no difference in the good corporate governance disclosure compliance between Malaysian and Bangladeshi Islamic banks against the alternative hypothesis, $\mathrm{H}_{\mathrm{A} 1}$ : corporate governance disclosure compliance of Malaysian Islamic banks is better than Bangladeshi Islamic banks. T-test has been applied to check the hypothesis and the following Table 6 highlights the results.

Table 6. Paired samples t-test for corporate governance: Bangladeshi and Malaysian banks

\begin{tabular}{|c|c|c|c|c|c|}
\hline & Mean & $\mathrm{N}$ & Std. Deviation & $\mathrm{t}$ & Sig. \\
\hline $\begin{array}{l}\text { Corporate Governance Disclosure Percentage: } \\
\text { Bangladeshi Banks }\end{array}$ & 80.0100 & 35 & 9.27362 & & \\
\hline $\begin{array}{l}\text { Corporate Governance Disclosure Percentage: } \\
\text { Malaysian Banks }\end{array}$ & 83.9714 & 35 & 14.78577 & & \\
\hline $\begin{array}{l}\text { Corporate Governance Disclosure Percentage: } \\
\text { Bangladeshi Banks and Malaysian Banks }\end{array}$ & -3.57143 & $34 \mathrm{df}$ & 20.35401 & -.464 & .659 \\
\hline
\end{tabular}

Table 6 shows the results of t-test where we find that the p vale is .659 indicating the significance level of the test. From these results, we can say that the null hypothesis can be accepted. Thus, our alternative hypothesis is rejected and hence we can conclude that there is no statistically significant difference regarding good corporate governance disclosure compliance between Malaysian and Bangladeshi Islamic banks though the mean corporate governance disclosure compliance percentage (about $84 \%$ ) is higher for Malaysian Islamic banks than that of Bangladeshi Islamic banks(about 80\%).

\subsection{Test for Association Between Good Corporate Governance and Risk Disclosures}

As earlier studies of Chen and Jaggi, (2000); Eng and Mak, (2003), Gul and Leung (2004), Healy and Palepu (2001) and Ho and Wong (2001) revealed a positive relationship between good corporate governance and greater risk disclosure in a single country perspective, we tried to test the same for two countries' (Bangladesh and Malaysia) Islamic banks with a corporate governance disclosure index combining the key issues of corporate governance of both the countries that are important beyond the boundaries.

Correlation analysis has been applied to test the null hypothesis, $\mathrm{H}_{\mathrm{O} 3}$ : There is no association between corporate risk disclosure and good corporate governance against the alternative hypothesis, $\mathrm{H}_{\mathrm{A} 3}$ : Corporate risk disclosure is 
positively associated with good corporate governance. The results of the test have been highlighted in the following table.

Table 7. Correlation between good corporate governance and risk disclosures

\begin{tabular}{lllll}
\hline & $\begin{array}{l}\text { Average Risk Related } \\
\text { Sentences in Bangladeshi and } \\
\text { Malaysian Islamic Banks }\end{array}$ & $\begin{array}{l}\text { Average Corporate Governance Sig } \\
\text { Disclosure Percentage in } \\
\text { Bangladeshi and Malaysian Islamic } \\
\text { Banks }\end{array}$ & N \\
& & Pearson Correlation: .573 & .032 & 14 \\
\hline $\begin{array}{l}\text { Average Risk Related } \\
\text { Sentences in Bangladeshi and } \\
\text { Malaysian Islamic Banks }\end{array}$ & Pearson Correlation: 1 & & \\
\hline $\begin{array}{l}\text { Average Corporate } \\
\text { Governance } \begin{array}{r}\text { Disclosure } \\
\text { Percentage in Bangladeshi } \\
\text { and Malaysian Islamic Banks }\end{array}\end{array}$ & Pearson Correlation: .573 & & .032 & 14 \\
\hline
\end{tabular}

Table 7 shows that the $\mathrm{p}$ vale is 0.032 and it indicates the significance of the test. From these results we can say that the null hypothesis may be rejected at $95 \%$ confidence level. Again the Pearson Correlation value of .573 ensures a moderate positive association. Thus, our alternative hypothesis is accepted and hence we can conclude that the corporate risk disclosure is positively associated with good corporate governance.

\section{Conclusions and Policy Implications}

Considering the quantity of risk disclosure it can be concluded that the risk reporting of Malaysian Islamic banks is far better than the Bangladeshi Islamic banks though corporate governance and relevant disclosures of the Malaysian banks is slightly better than that of Bangladeshi Islamic banks. Again the results of the research suggest that the risk disclosure is positively associated with good corporate governance. But when we keep the risk reporting in the spot light of quality measurement, we get a frustrating picture as the findings of the paper bring no difference from the earlier research outcomes who found the risk disclosures in annual reports were not company specific and hence investors do not get assistance from such information to choose the right company to investment (Abraham \& Cox, 2007; ASB, 2009; Lajili \& Zéghal, 2005; Linsley \& Shrives, 2006; Solomon et al., 2000). The results of the study help to come to a decision that the present risk reporting practice is similar to 'window dressing' where the information disclosure is general and standardized in nature without regular update in each year. More importantly, real risk experiences of the banks and the way they met it and strategy to mitigate such risks in future are absent in the annual reports. Since strategic managers of the Islamic banks take their investment decision considering the real risk they faced earlier, facing now and expecting to face in the future, it is obvious that they do not disclose all the information in the annual report for the stakeholders. Though the reason of such non-disclosure is not clear (Marshall \& Weetman, 2007), proprietary costs as discussed in this research may be an important catalyst in this regard.

Since the problem lies in the proprietary cost theory and institutional theory, the solution must be searched in these theories as well. The important issue needs to be considered in this regard is the way to implement the improvement process. Thus, certain banks (for example banks where govt. possesses a good portion of ownership) may start improving disclosures in spite of incurring some proprietary costs. Since the institutional cost theory refers the mimicking behavior of firms in disclosures, other banks may start disclosing important and real risk issues like the initiating banks.

As good corporate governance is positively associated with better risk disclosure, the corporate governance code may consist of a policy for asking explanation of non-disclosing real risk issues. At the same time, the investors may have been given the right to seek investment relevant information from the banks in which he invested or want to invest. If any company denies in providing such information, there should be some provision to ask for help from competent authority like Security and Exchange Commission.

In addition, compliance with IFRS \# 8 can also be an important factor in this regard as under this standard companies ought to disclose the same information in the annual reports which they applies internally for decision making. 


\section{References}

Abdallah, A. A. N., Hassan, M. K., \& McClelland, P. L. (2015). Islamic financial institutions, corporate governance, and corporate risk disclosure in Gulf Cooperation Council countries. Journal of Multinational Financial Management, 31, 63-82. https://doi.org/10.1016/j.mulfin.2015.02.003

Abraham, S., \& Cox, P. (2007). Analysing the determinants of narrative risk information in UK FTSE 100 annual reports. The British Accounting Review, 39(3), 227-248. https://doi.org/10.1016/j.bar.2007.06.002

Abraham, S., \& Shrives, P. J. (2014). Improving the relevance of risk factor disclosure in corporate annual reports. The British Accounting Review, 46(1), 91-107. https://doi.org/10.1016/j.bar.2013.10.002

Ahmed, U., Khalid, N., Ammar, A., \& Shah, M. H. (2017). Assessing moderation of employee engagement on the relationship between work discretion, job clarity and business performance in the banking sector of Pakistan. Asian Economic and Financial Review, 7(12), 1197-121.

Archer, S., Karim, R. A. A., \& Al-Deehani, T. (1998). Financial contracting, governance structures and the accounting regulation of Islamic banks: an analysis in terms of agency theory and transaction cost economics. Journal of Management and Governance, 2(2), 149-170. https://doi.org/10.1023/A:1009985419353

Berger, A. N., \& Di Patti, E. B. (2006). Capital structure and firm performance: A new approach to testing agency theory and an application to the banking industry. Journal of Banking \& Finance, 30(4), 1065-1102.

Cabedo, J. D., \& Tirado, J. M. (2004, June). The disclosure of risk in financial statements. Accounting Forum, 28(2), 181-200. https://doi.org/10.1016/j.accfor.2003.10.002

Campbell, D., \& Slack, R. (2008). Corporate "philanthropy strategy" and "strategic philanthropy" some insights from voluntary disclosures in annual reports. Business \& Society, 47(2), 187-212.

Chen, C. J., \& Jaggi, B. (2001). Association between independent non-executive directors, family control and financial disclosures in Hong Kong. Journal of Accounting and Public Policy, 19(4), 285-310.

Coase, R. H. (1937). The nature of the firm. Economica, 4(16), 386-405.

Conyon, M. J., \& Schwalbach, J. (2000). European differences in executive pay and corporate governance. Corporate Governance (pp. 97-114). Gabler Verlag.

Cormier, D., Magnan, M., \& Van Velthoven, B. (2005). Environmental disclosure quality in large German companies: economic incentives, public pressures or institutional conditions?. European Accounting Review, 14(1), 3-39. https://doi.org/10.1080/0963818042000339617

Dillard, J. F., Rigsby, J. T., \& Goodman, C. (2004). The making and remaking of organization context: duality and the institutionalization process. Accounting, Auditing \& Accountability Journal, 17(4), 506-542.

DiMaggio, P., \& Powell, W. (983). The iron cage revisited: institutional isomorphism and collective rationality in organizational fields. American Sociology Review, 48(2), 147-160. https://doi.org/10.2307/2095101

Dincer, N., \& Kilinç, Z. (2018). The Analysis of Stress Levels of the Female Wrestlers Studying in Higher Education (A Case of Batman Province). Asian Journal of Education and Training, 4(3), 156-160.

Dunst, C. J., Raab, M., Embler, D., \& Roberts, K. (2018). Developing Evidence-Informed Early Childhood Intervention E-Learning Lessons, Performance Checklists and Practice Guides. Journal of Education and e-Learning Research, 5(4), 242-248. https://doi.org/10.20448/journal.509.2018.54.242.248

Durak, G., \& Çankaya, S. (2018). Seamless Learning: A Scoping Systematic Review Study. Journal of Education and E-Learning Research, 5(4), 225-234. https://doi.org/10.20448/journal.509.2018.54.225.234

Ebire, K., Onmonya, O., \& Inim, V. E. (2018). Effects of the Determinants of Foreign Direct Investment in Nigeria: Error Correction Mechanism. Asian Journal of Economics and Empirical Research, 5(2), 155-164.

Eketu, C. A. (2018). Perspectives on Human Nature and Implications for Research in the Behavioural Sciences. International Journal of Emerging Trends in Social Sciences, 4(1), 42-46.

Elshandidy, T., Fraser, I., \& Hussainey, K. (2013). Aggregated, voluntary, and mandatory risk disclosure incentives: Evidence from UK FTSE all-share companies. International Review of Financial Analysis, 30, 320-333.

Eng, L. L., \& Mak, Y. T. (2003). Corporate governance and voluntary disclosure. Journal of Accounting and Public Policy, 22(4), 325-345. https://doi.org/10.1016/S0278-4254(03)00037-1

Gul, F. A., \& Leung, S. (2004). Board leadership, outside directors' expertise and voluntary corporate disclosures. 
Journal of Accounting and Public Policy, 23(5), 351-379. https://doi.org/10.1016/j.jaccpubpol.2004.07.001

Gürsoy, G., \& Aydoğan, K. (2002). Equity ownership structure, risk taking, and performance: an empirical investigation in Turkish listed companies. Emerging Markets Finance \& Trade, 6-25.

Hassan, M. K. (2014). Risk narrative disclosure strategies to enhance organizational legitimacy: Evidence from UAE financial institutions. International Journal of Disclosure and Governance, 11(1), 1-17.

Healy, P. M., \& Palepu, K. G. (2001). Information asymmetry, corporate disclosure, and the capital markets: A review of the empirical disclosure literature. Journal of Accounting and Economics, 31(1), 405-440.

Hernández-Madrigal, M., Blanco-Dopico, M. I., \& Aibar-Guzmán, B. (2012). The influence of mandatory requirements on risk disclosure practices in Spain. International Journal of Disclosure and Governance, 9(1), 78-99. https://doi.org/10.1057/jdg.2011.22

Hooks, J., \& van Staden, C. J. (2011). Evaluating environmental disclosures: The relationship between quality and extent measures. The British Accounting Review, 43(3), 200-213. https://doi.org/10.1016/j.bar.2011.06.005

Ihsan, A. (2017). Measuring the Efficiency of Tertiary Care Hospitals and Medical Colleges in Punjab, an Application of Non-Parametric Approach DEA. Asian Journal of Economics and Empirical Research, 4(1), 14-24. https://doi.org/10.20448/journal.501.2017.41.14.24

Imran, A., \& Bakari, H. (2018). Co-Movement between Macroeconomic Variables and Capital Flight. Asian Economic and Financial Review, 8(9), 1185-1195. https://doi.org/10.18488/journal.aefr.2018.89.1185.1195

Inan, T. (2018). Home Field Advantage Calculation for Physical Education and Sport Students. Asian Journal of Education and Training, 4(1), 45-50. https://doi.org/10.20448/journal.522.2018.41.45.50

Jensen, M. C., \& Meckling, W. H. (1976). Theory of the firm: Managerial behavior, agency costs and ownership structure. Journal of Financial Economics, 3(4), 305-360. https://doi.org/10.1016/0304-405X(76)90026-X

Jermsittiparsert, K. (2016). Culture of 'Elephant front legs-hind legs': A debate on the actuality of sexual politics in Thai society. The Social Sciences, 11(1), 20-28.

Kamal Hassan, M. (2009). UAE corporations-specific characteristics and level of risk disclosure. Managerial Auditing Journal, 24(7), 668-687. https://doi.org/10.1108/02686900910975378

Karim, R. A. A. (2001). International accounting harmonization, banking regulation, and Islamic banks. The International Journal of Accounting, 36(2), 169-193. https://doi.org/10.1016/S0020-7063(01)00093-0

Lara, J. M. G., Osma, B. G., \& Penalva, F. (2009). Accounting conservatism and corporate governance. Review of Accounting Studies, 14(1), 161-201. https://doi.org/10.1007/s11142-007-9060-1

Linsley, P. M., \& Lawrence, M. J. (2007). Risk reporting by the largest UK companies: readability and lack of obfuscation. Accounting, Auditing \& Accountability Journal, 20(4), 620-627.

Lopes, P. T., \& Rodrigues, L. L. (2007). Accounting for financial instruments: An analysis of the determinants of disclosure in the Portuguese stock exchange. The International Journal of Accounting, 42(1), 25-56.

Marshall, A., \& Weetman, P. (2007). Modelling transparency in disclosure: the case of foreign exchange risk management. Journal of Business Finance \& Accounting, 34(5-6), 705-739.

Marston, C. L., \& Shrives, P. J. (1991). The use of disclosure indices in accounting research: a review article. The British Accounting Review, 23(3), 195-210. https://doi.org/10.1016/0890-8389(91)90080-L

McDonough, W. J. (2002). Issues in corporate governance. BIS Review, 57, 2002.

Mitton, T. (2002). A cross-firm analysis of the impact of corporate governance on the East Asian financial crisis. Journal of Financial Economics, 64(2), 215-241. https://doi.org/10.1016/S0304-405X(02)00076-4

Moxey, P., \& Berendt, A. (2008). Corporate governance and the credit crunch. ACCA, London.

Oliveira, P., \& von Hippel, E. (2011). Users as service innovators: The case of banking services. Research Policy, 40(6), 806-818. https://doi.org/10.1016/j.respol.2011.03.009

Oliver, C. (1991). Strategic responses to institutional processes. Academy of Management Review, 16(1), 145-179.

Poskitt, R. (2005). Disclosure regulation and information risk. Accounting and Finance, 45(3), 457-477.

Raffaele, P. (2006). In John They Trust-In the South Pacific nation of Vanuatu, some islanders pray to a god they call John Frum, frequently characterized as an American sailor stationed there during World War II. 
Smithsonian, 36(11), 70 .

Ramalingegowda, S., \& Yu, Y. (2012). Institutional ownership and conservatism. Journal of Accounting and Economics, 53(1), 98-114. https://doi.org/10.1016/j.jacceco.2011.06.004

Safieddine, A. (2009). Islamic financial institutions and corporate governance: New insights for agency theory. Corporate Governance: An International Review, 17(2), https://doi.org/10.1111/j.1467-8683.2009.00729.x

Sarker, M. A. A. (1999). Islamic banking in Bangladesh: performance, problems, and prospects. International Journal of Islamic Financial Services, 1(3), 15-36.

Shahzad Bukhari, K., Awan, H. M., \& Ahmed, F. (2013). An evaluation of corporate governance practices of Islamic banks versus Islamic bank windows of conventional banks: A case of Pakistan. Management Research Review, 36(4), 400-416. https://doi.org/10.1108/01409171311315003

Suryanto, T., Haseeb, M., \& Hartani, N. H. (2018). The Correlates of Developing Green Supply Chain Management Practices: Firms Level Analysis in Malaysia. International Journal of Supply Chain Management, 7(5), 316.

Verrecchia, R. E. (1983). Discretionary disclosure. Journal of Accounting and Economics, 5, 179-194.

Weber, E. U., Siebenmorgen, N., \& Weber, M. (2005). Communicating asset risk: how name recognition and the format of historic volatility information affect risk perception and investment decisions. Risk Analysis, 25(3), 597-609. https://doi.org/10.1111/j.1539-6924.2005.00627.x

\section{Appendix}

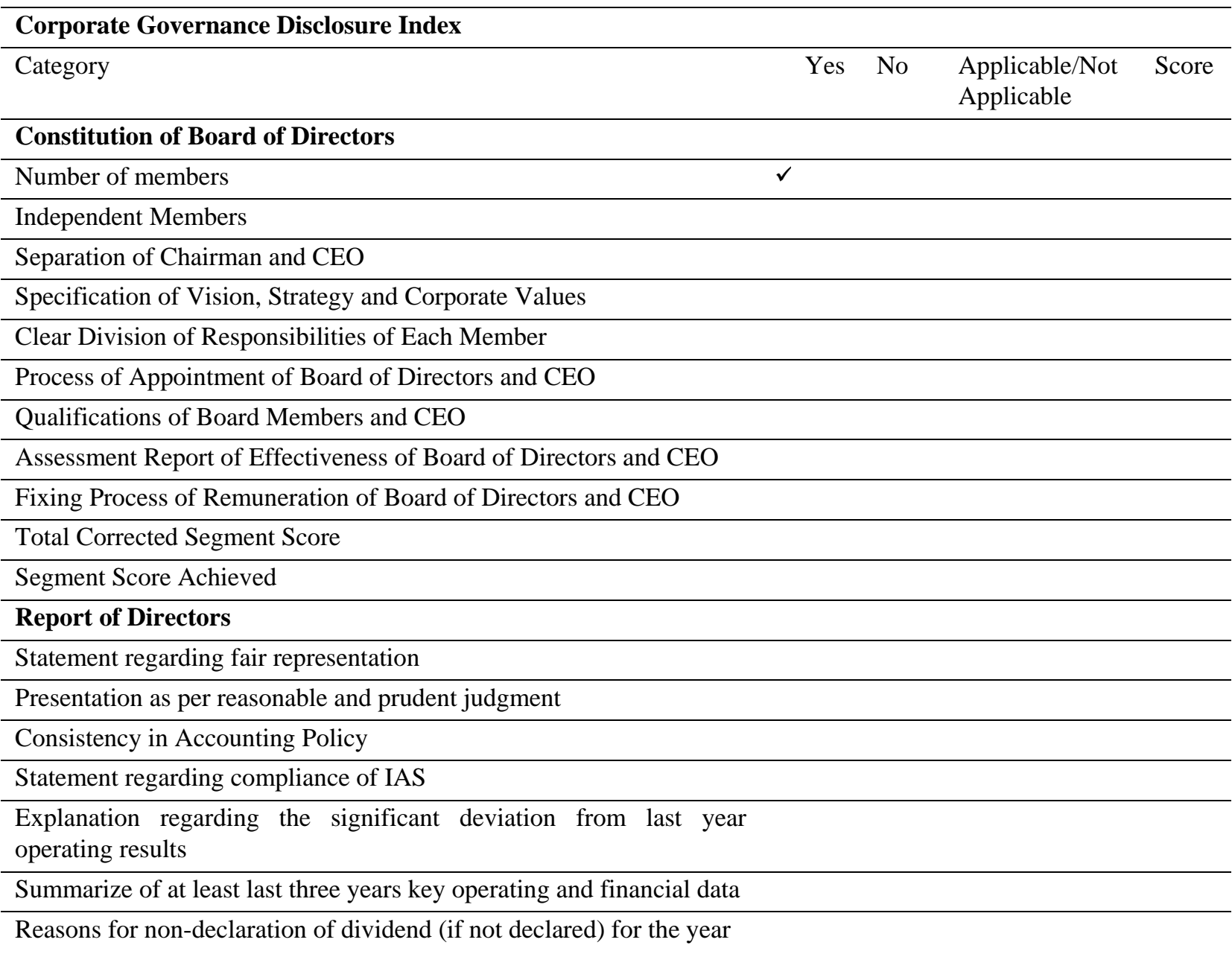


Significant plans and decisions along with future prospects and Risk

Number of Board Meetings held during the year

Total Corrected Segment Score

Segment Score Achieved

\section{Information of Key Issues}

Aggregate number of shares held by Parent/Subsidiary/Associate companies

Directors, CEO, Company Secretary, CFO, Head of Internal Audit and their spouse and minor children,

Top five salaried employees other than the above mentioned persons

Shareholders holding ten percent or more voting interest in the company

Information on appointment of a Chief Financial Officer (CFO), a Head of Internal Audit and a Company Secretary.

Total Corrected Segment Score

Segment Score Achieved

\section{Constitution of Audit Committee}

Number of members (At least 3)

Number of Independent members (At least 3)

Total Corrected Segment Score

Segment Score Achieved

\section{Contents Audit Report}

conflict of interest

Suspected or presumed fraud or irregularity or material defect in the internal control system (if any)

Suspected infringement of laws (if any)

The company will not engage its external/statuary auditors to provide the Bookkeeping, Broker-dealer, and Actuarial, Internal audit services or any other service that the Audit committees determine.

Customer satisfaction

Total Corrected Segment Score

Segment Score Achieved

Constitution of Shariah Board

Number of members

Independent Members

Functions of SB

Report of SB

Total Corrected Segment Score

Segment Score Achieved

Total Corrected Segment Score

Segment Score Achieved 